\title{
Kajian Makna Simbolis Patung dan Monumen di Kabupaten Ponorogo Sebagai Sumber Pembelajaran Sejarah Lokal
}

\author{
Nanda Cahyo Setiaji ${ }^{1}$, Muhammad Hanif ${ }^{2}$ \\ ${ }^{1}$ Alumni Pendidikan Sejarah FKIP Universitas PGRI Madiun \\ ${ }^{2}$ Dosen Program Studi Magister Pendidikan IPS Pascasarjana Universitas PGRI Madiun
}

\begin{abstract}
Abstrak
Penelitian ini bertujuan untuk mengetahui kajian makna simbolis patung dan monumen sebagai pembelajaran sejarah lokal, serta untuk mengetahui potensi-potensi lain yang terjadi pada masa yang akan datang di Kabupaten Ponorogo.

Penelitian dilakukan di Kabupaten Ponorogo mulai bulan Februari sampai bulan Juli 2015. Sumber data penelitian ini adalah (a) sumber data primer, yaitu sumber data dari informan individu maupun perseorangan, (b)sumber data yang bersifat sekunder, yaitu data yang diperolehdokumen, foto dan rekaman video hasil observasi lapangan. Pengumpulan data menggunakan wawancara, observasi langsung, dokumentasi tertulis dengan teknik triangulasi. Analisis data menggunakan kualitatif model interaktif. Pendekatan penelitian ini adalah menggunakan jenis deskripstif-kualitatif.

Hasil penelitian menunjukkan bahwa sejarah berdirinya patung dan monumen di Ponorogo tidak lepas dari kepiawian Bupati terdahulu, yaitu Dr. H. Markum Singodimedjo, MM yang telah membangun simbol-simbol patung cerita Reog dari sumbangan pihak ketiga. Tujuannya untuk tata keindahan kota serta lebih menonjolkan nuansa kota Reog. Dengan dibangunnya patung dan monumen tersebut diharapkan dapat meningkatkan kepariwisataan dan menjadi sumber pembelajaran sejarah lokal, agar generasi penerus lebih menghargaikearifan budaya luhur yang telah dimiliki.
\end{abstract}

Kata Kunci: makna simbolis, patung, monumen, pembelajaran sejarah lokal

\section{Pendahuluan}

Kabupaten Ponorogo dikenal dengan julukan Kota Reog atau Bumi Reog karena daerah ini merupakan daerah asal dari kesenian Reog. Ponorogo juga dikenal sebagai Kota Santri karena memiliki banyak pondok pesantren, salah satu yang terkenal adalah Pondok Modern Darussalam Gontor yang terletak di desa Gontor, kecamatan Mlarak. Nama Ponorogo berasal dari kata Pramana Raga, yang akhirnya ucapan Pramana berubah menjadi: Pana (mengerti) dan raga (awak/badan).

Jadi Ponorogo mengandung maksud orang yang dapat menempatkan dirinya dihadapan orang lain (Soemarto, 2011: 15).
Kabupaten Ponorogo terletak pada $111^{\circ} 7^{\prime}$ hingga $111^{\circ} 52^{\prime}$; Bujur Timur $7^{\circ} 49^{\prime}$ hingga $8^{\circ} \quad 20^{\prime}$ Lintang Selatan dan langsung berbatasan dengan Kabupaten Magetan, Kabupaten Madiun dan Kabupaten Nganjuk di sebelah utara. Di sebelah timur berbatasan dengan Kabupaten Tulungagung dan Kabupaten Trenggalek; sebelah selatan dengan Kabupaten Pacitan.

Sebelah barat berbatasan dengan Kabupaten Pacitan dan Kabupaten Wonogiri (Provinsi Jawa Tengah). Luas wilayah Kabupaten Ponorogo yang mencapai $1.371,78 \mathrm{~km}^{2}$ yang secara administratif terbagi menjadi 21 kecamatan, 307 desa/kelurahan: Badan Perencanaan 
Pembangunan Daerah (2014: 1). Kota merupakan wadah dari berbagai aspek kehidupan yang sangat kompleks, oleh karena itu penggambaran kota secara teoritis sangat rumit. Bagi seorang ahli ekologi kota dipandang sebagai masalah kependudukan yang terpisah-pisah karena latar belakang kemakmuran dan kebudayaan (Basundoro, 2012: 14).

Kota ponorogo bisa juga disebut kota budaya karena hasil kebudayaanya yaitu kesenian Reog Ponorogo dikenal di Indonesia bahkan dunia internasional. Dalam perkembanganya Kota Ponorogo banyak membangun patung dan monomen yang menceritakan ketokohan dari kesenian Reog tersebut dan dapat dijadikan sebagai sumber pembelajaran sejarah lokal dan nilai-nilai kearifan lokal bila digali secara mendalam.

Patung tersebut diantaranya patung Dewi Songgolangit yang berada di Pendopo Kabupaten Ponorogo, Dewi Songgolangit merupakan putri mahkota dari Kerajaan Kediri yang di perebutkan Prabu Klono Sewandhana dan dibantu patihnya Bujang Anom dalam salah satu versi cerita Reog Ponorogo.

Tidak kalah dengan Dewi Songgolangit patung Prabu Klono Sewandhana juga diukir dalam bentuk munumen bersejarah yang berada di Dusun Bantarangin, Desa Sumoroto, Kecamatan Kauman Ponorogo. Sejak diresmikan tahun 2011 di bangun oleh Pemeritah Ponorogo, tempat ini dipercaya sebagai bekas kerajaan Bantarangin. Sejak saat itu pada waktu bulan suro (bulan jawa) diadakan kirab yang berawal dari Desa Carat, Kauman Ponorogo dan behenti di lokasi monumen Bantarangin.

Bujang Anom adalah patih Prabu Klono Sewandhana dalam cerita Reog Ponorogo. Bujang Anom sebagai Ganong atau sering disebut Ganongan, dikisahkan Ganongan melawan Singo Barong yang di utus Prabu Klono Sewandhana tetapi dalam pertempuran ganongan kalah, wujud ganongan diabadikan dalam sebuah patung yang pertama diperempatan Tambak Bayan, arah utara Jalan MT. Hariyono, arah sebelah timur Jalan Urip Sumoharjo, arah sebelah selatan Jalan Diponegoro, dan arah sebelah barat Jalan Turnojoyo. Patung yang kedua berada di dekat terminal lama, arah sebelah utara Jalan Sultan Agung, arah sebelah timur Jalan Ir. Juanda, arah sebelah selatan Jalan Basuki Rahmat, dan arah barat Jalan Gajah Mada yang berpose gaya khas Ganongan.

Warok adalah salah satu penari dalam seni reog, warok diterjemahkan sebagai sosok yang dikenal sebagai seorang yang mempunyai ilmu kanuragan dan digambarkan berbadan gempal dengan bulu dada, kumis berjambang lebat serta mata yang tajam lebih dari itu seorang warok mempunyai senjata wasiat kolor sakti. Sosok warok diabadikan sebuah patung yang pertama berada di pertigaan Ngepos, arah sebelah utara Jalan Soekarno-Hata, 
arah sebelah timur Jalan Gajah Mada, dan arah sebelah barat Jalan Jendral Sudirman. Patung yang kedua berada diperempatan Njeruk sing, arah sebelah utara Jalan Letjen Suprapto, arah sebelah timur Jalan $\mathrm{H}$. Perdana Kusuma, arah sebelah selatan Jalan Ki Ageng Kutu, dan arah sebelah barat Jalan Ir. Juanda. Kedua patung ini dibagun dengan tangan mengangkat keatas dengan sorotan mata tajam melambangkan keberanian seorang warok sejati.

Jatilan dilambangkan prajurit perang berkuda dan salah satu personil dalam tari Reog, dahulu seorang jatilan diperankan oleh seorang laki-laki yang halus berparas rupawan manis mirip wanita dan sering disebut gemblak tetapi dalam perkembangan kesenian Reog digantikan oleh seorang wanita yang umumnya masih perawan agar lebih menarik dan memikat penonton. Jatilan juga banyak diabadikan dalam berbagai kelompok patung Reog.

Salah satunya yang berada di perbatasan Mlilir Ponorogo atau yang dikenal dengan sebutan tugu Reog. Selain itu juga dibangun disebelah selatan Stadion Batoro Katong untuk menghiasi artistik pintu masuk Stadion dari arah selatan. Langsung terlihat jelas bila dilihat dari selatan Jalan Baru atau Jalan Suromenggolo, dan bisa kita lihat pesona patung dari arah yang berbeda, yaitu dari arah barat kearah timur Jalan Pramuka akan melewati patung Jatilan tersebut, seolah-olah patung itu menyambut kedatangan masyarakat yang ingin masuk ke dalam area Stadion Batoro Katong. Patung yang terakhir adalah patung macan, mengapa patung macan banyak dibangun di Kota Ponorogo?.

Hal itu yang sering kali menjadi pertanyaan masyarakat, serta melekat di ingatan setiap kali membicarakan Kota Ponorogo, seolah sudah menjadi trademark kota. Bisa dikatakan macan sudah tidak asing lagi dalam kesenian Reog Ponorogo. Hal ini dikarenakan macan menyimbulkan singo barong atau singo lodro dalam cerita reog versi Bantarangin.

Macan diceritakan sebagai Singo lodro yang juga berkeinginan meminang Dewi Songgolagit, kemudian Singo lodro menghadang Klono Sewandhana pertempuran pun tidak dapat dihindarkan akhirnya singo lodro dapat dilumpuhkan dengan senjata pecut samandiman milik Prabu Klono Sewandhana sehingga terjadi cerita Reog yang melegenda hingga kini.

Masyarakat harus menghargai dan mempelajari kebudayaan asli Ponorogo khususnya generasi muda sehingga nilai akan kebudayaan tersebut akan tetap lestari, hal ini dapat dipelajari melalui simbolis patung dan munumen yang berada dibeberapa perempatan dan kawasan kota Ponorogo. Karya-karya patung modern menggunakan aneka bahan dan teknik,sehingga banyak alternatif, banyak pula karya patung yang kemudian menjadi monumen di bebagai kota (Budiman, 2008: 44). Karya patung modern saat ini mulai 
berkembang pesat seiring dengan kebutuhan dalam mengarungi perubahan gaya hidup di lingkungan kita. Praptanto (2010: 64) mengatakan patung skala kota banyak sekali dibangun selain untuk memperindah kota, juga dimaksudkan sebagai ekspresi memperingati jasa pahlawan dan semangat kepahlawanan.

Kemampuan manusia untuk memainkan perannya pada masa kini dalam rangka mewujudkan masa depan yang dicita-citakan sangat ditentukan pemahaman jiwa dan semangat masa lampau dengan baik. Hal ini menunjukkan bahwa kesinambungan harus terus dijaga karena tidak ada peristiwa atau kejadian yang tidak ada hubungannya dengan peristiwa lain di dunia ini. Keberhasilan dan kegagalan sudah banyak tertulis oleh sejarah, tinggal bagaimana kita bisa belajar. Salah satu upaya pembangunan karakter bangsa dapat dilakukan melalui pendidikan sejarah yang mulai diberikan sejak pendidikan dasar.

Pendidikan sejarah diharapkan dapat memberikan wawasan berkenaan dengan peristiwa-peristiwa dari berbagai periode dalam upaya pembentukan sikap dan perilaku siswa. Sejarah adalah suatu studi keilmuan tentang segala yang telah dialami manusia di waktu yang lampau dan yang telah meninggalkan jejek-jejaknya di waktu sekarang, dimana tekanan perhatian diletakkan pada aspek peristiwanya sendiri kemudian disusun dalam suatu cerita sejarah (Rochmat, 2009: 9). Kesadaran akan sejarah pada dasarnya dimiliki oleh setiap masyarakat, dan mereka secara tidak langsung sering mengajarkan sejarah dalam kehidupan sehari-hari. Sebagai contoh dalam keluarga, sejak kecil seorang anak akan dikenalkan dengan silsilah keluarga oleh orang tua agar mengetahui siapa saudara mereka.

Dalam kehidupan masyarakat, pendidikan sejarah secara informal sering disampaikan melalui folklore atau tradisi sejarah lisan, misal; cerita asal-usul nama daerah atau cerita-cerita kepahlawanan pada masa lalu. Sudah seharusnya materi pelajaran sejarah yang diajarkan di sekolah khususnya pembelajaran IPS mengenai sejarah lokalnya dapat diambil dari nilainilai yang muncul atau sudah ada dan lama tertanam di masyarakat.

Kota Ponorogo jika digali kearifan lokalnya akan mendatangkan pengetahuan yang baru dan unik, dengan demikian warga Ponorogo harus bangga dengan kotanya. Tujuan penelitian untuk mengungkap Latar belakang sejarah dan makna simbolis keberadaan patung dan monumen Kabupaten Ponorogo, serta potensinya sebagai sumber pembelajaran sejarah lokal.

\section{Tinjauan Pustaka}

\section{A. Patung}

\section{Pengertian Patung}

Patung merupakan tiruan bentuk orang, hewan, dibuat dipahat dari kayu dan batu, dan sebagainya (KBBI, 2008: 1031). 
Patung merupakan cabang seni rupa murni yang berwujud tiga dimensi (panjang, tinggi, lebar, dan tebal/berisi). Seni patung, sering digunakan bahan dari batu, kayu, tanah liat, logam, resin, serta bahan lain, yang sesuai dengan jiwa atau ekspresi senimannya (Budiman, 2008: 4).

Seni patung sudah dikenal bangsa Indonesia sebelum mendapatkan pengaruh dari kebudayaan Hindhu-Budha. Sejumlah arca dalam berbagai ukuran telah ditemukan diberbagai tempat di Indonesia pada sekitar abad ke-2. Keterampilan memahat yang dimiliki bangsa Indonesia merupakan modal awal yang berharga bagi perkembangan seni patung setelah masuknya Hindu-Budha (Darini, 2013: 80).

Berdasarkan pendapat di atas maka dapat disimpulkan bahwa patung merupakan sebuah karya seni tiga dimensi. Proses pembuatanya biasanya dengan pengukir terbuat dari batu atau kayu dan sudah lama dikenal oleh nenek moyang kita sebelum agama Hindu-Budha masuk di Indonesia. Pada zaman klasik, patung dibuat untuk menghiasi tempat peribadatan HinduBudha, seperti candi Prambanan dan Borobudur. Di era modern saat ini, seni patung dibuat untuk menghias bangunan ataupun monumen.

\section{Perkembangan Seni Patung di Indonesia}

Seni patung di Indonesia berkembang produktif seiring didirikanya berbagai bangunan candi diberbagai tempat dan berbagai zaman. Biasanya dalam bangunan candi banyak ditemukanya arca sebagai bagian dari komponen candi (Darini, 2013: 81). Soekarno mencanangkan pembangunan berbagai proyek yang dikenal sebagai politik Mercu Suar Bung Karno. Proyek yang dibangun pertama kali adalah kompleks bangunan untuk fasilitas olah raga, yaitu gelanggang olah raga.

Pada tahun 1962, Indonesia ditetapkan sebagai tuan rumah penyelenggaraan Asian Games IV, sejak saat itu patung skala kota (patung dan skala besar sehingga berfungsi sebagai landmark kota), banyak sekali dibangun. Selain memperindah kota, juga sebagai ekspresi memperingati jasa pahlawan dan semangat kepahlawanan Indonesia, antara lain Patung Selamat Datang, Patung Pahlawan Diponegoro, Patung Tani, Patung Pembebasan Irian Barat, dan Patung Dirgantara (Praptanto, 2010: 64).

\section{B. Monumen}

\section{Pengertian Monumen}

Monumen adalah bangunan atau tempat yang mempunyai nilai sejarah yang penting dan karena itu dipelihara dan dilindungi negara (KBBI, 2008: 928). Monumen perjuangan bangsa sangat penting keberadaanya. Karena monumen tersebut, merupakan suatu prasasti, peninggalan sejarah yang sangat penting bagi generasi mendatang sebagai generasi penerus dalam mengisi kemerdekaan bangsa Indonesia (Monumen Palagan 
Ambarawa, 1974: 7). Berdasarkan pengertian tersebut, maka monumen adalah upaya manusia untuk mengabadikan bukti peristiwa sejarah. Menurut tujuannya, monumen dibuat dengan kesengajaan memang untuk sebuah peninggalan, agar generasi yang akan datang tetap mengenang suatu peristiwa bersejarah.

\section{Perkembangan Monumen di}

\section{Indonesia}

Pada awal kemerdekaan Indonesia pemeritah masa itu berusaha menanamkan rasa nasionalisme (cinta tanah air) agar generasi muda waktu itu mewarisi semangat juang 1945. Orde lama berusaha menanamkan paham nasionalis sehingga dikemudian hari Soekarno membentuk PNI (Partai Nasional Indonesia). Orde lama adalah sebutan yang diberikan oleh rezim Orde Baru yang mengacu pada pemerintahan Presiden Soekarno (Praptanto, 2010: 2).

Pemerintah pada masa itu berusaha membangun monumental diberbagai kota di Indonesia gunanya mengenang peristiwa bersejarah dan menunjukkan kepada dunia Internasional. Soekarno juga merancang tugu peringatan berbentuk lilin atau paku raksasa, yang menyerupai bentuk phallus atau obelisk.

Bentuk phallus untuk monumen dieksplorasi dari budaya Jawa kuno (Hindu) dan direalisasikan ke dalam rancangan monumen, diantaranya: Tugu proklamasi (Jakarta), Tugu Muda (Semarang), Tugu
Alun-Alun Bunder (Malang), dan Tugu Pahlawan (Surabaya). Bangunan yang cukup monumental adalah Tugu Monumen Nasional (MONAS) yang berbentuk lingga yoni (Praptanto, 2010: 64-65).

\section{Makna Simbolis}

Menurut Herusatoto (2008: 17) arti kata simbol berasal dari kata Yunani symbolos yang berarti tanda atau ciri yang memberitahukan sesuatu hal kepada seseorang. Selain itu, Saifudin (2006: 289290) juga mengatakan bahwa simbol adalah objek, kejadian, bunyi bicara, atau bentuk tertulis yang diberi makna oleh manusia, bentuk primer dari simbolisasi oleh manusia adalah melalui bahasa.

Namun, manusia juga berkomunikasi dengan menggunakan tanda dan simbol dalam lukisan, tarian, musik dan sebagainya. Hal senada juga dikatakan simbolis/sim.bo·lis/a sebagai lambang; menjadi lambang; mengenai lambang: lukisan (Kamus Besar Bahasa Indonesia, 2008: 1308). Berdasarkan beberapa pengertian diatas, makna simbolis dapat didefinisikan sebagai suatu bentuk aktivitas yang merupakan ciri khas manusia yakni penggunaan komunikasi atau pertukaran simbol yang diberi makna agar mereka dapat saling berinteraksi.

Manusia adalah mahkluk budaya, dan budaya manusia penuh dengan simbolsimbol, sehingga dapat dikatakan bahwa budaya manusia penuh diwarnai dengan 
simbolisme (Herusatoto, 2008: 46). Sepanjang sejarah budaya manusia simbolisme telah mewarnai tindakantindakan manusia baik tingkah laku, bahasa, ilmu pengetahuan, maupun religinya.

Kebudayaan yang dihasilkan oleh manusia, tidak selamanya dapat berupa hal yang nyata, dengan kata lain sesuatu yang dapat ditangkap oleh indra penglihatan yang dapat diraba dan disentuh secara langsung, tetapi ada budaya yang dihasilkan manusia secara tersembunyi, atau hanya terwakili oleh sesuatu saja. Dengan begitu, untuk menyebutkannya, hanya terwakili dan untuk menjelaskannya barulah ia bisa terungkap secara gamblang dari apa yang dimunculkannya.

\section{Sejarah Lokal}

\section{Pengertian Sejarah Lokal}

Sejarah lokal adalah sejarah dari suatu "tempat", suatu "locality", yang batasnya ditentukan oleh "perjanjian" yang diajukan penulis sejarah. Batas geografisnya dapat suatu tempat tinggal suku bangsa, yang kini mungkin telah mencakup dua atau tiga daerah administratif tingkat dua atau tingkat suku (umpamanya, suku bangsa Jawa) dan dapat pula suatu kota, atau justru suatu desa (Abdullah, 1990: 15).

Selain pendapat tersebut, makna pengertian sejarah lokal dapat diartikan sebagai suatu tempat atau ruang sehingga sejarah lokal menyangkut lokalitas tertentu yang disepakati oleh penulis sejarah, atau sejarawan dengan alasan ilmiah, misalnya: suatu ruang tempat tinggal suku bangsa atau sub-suku bangsa (Sugeng Priyadi, 2012: 16-17).

Dari pengertian tersebut maka pengertian sejarah lokal adalah kegiatan atau penelitian di daerah tertentu yang mencakup kondisi geografis, nilai historis, dan tata letak daerah yang dibatasi oleh sejarawan, sehingga dapat digunakan untuk sarana pembelajaran.

\section{Klasifikasi Sejarah Lokal}

Sejarah lokal di Indonesia sejak tahun 1950 sesuai pendapat dari Abdullah (1990: 27) menyebutkan secara garis besar corak sejarah lokal yang pernah dilakukan tentang Indonesia dapat dibedakan menjadi empat corak, yaitu:

a) Studi yang difokuskan pada suatu peristiwa tertentu (studi peristiwa khusus atau apa yang disebut evenemental I'evenement).

b) Studi yang lebih menekankan pada stuktur.

c) Studi yang mengambil perkembangan aspek tertentu dalam kurun waktu tertentu (studi tematis), dan

d) Studi sejarah umum, yang menguraikan perkembangan daerah tertentu (provinsi, kota, kabupaten)dari masa ke masa, keempat corak ini tidak bersifat eksklusif, suatu corak dapat mengandung unsur-unsur yang lain, dan corak ini lebih ditentukan unsur dominan. 
Tingkat yang dibicarakan begitu dekat dengan objek sebenarnya dari penelitian sejarah, yaitu manusia. Maka pengerjaan sejarah lokal tidak dapat dianggap sebagai latihan sekunder. Mereka menuntut kemampuan teknis dan daya analisis tinggi. Bahkan tingkat abstraksi yang lebih rendah, maka pengerjaan sejarah lokal juga menuntut kecermatan dan ketelitian yang tajam. Tak jarang, sering terjadi penurunan tingkat abstraksi menuntut bantuan dari disiplin ilmiah lain, diantaranya jaringan sosial dan kultural.

\section{Metode Penelitian}

Penelitian dilaksanakan di Kabupaten Ponorogo Provinsi Jawa timur. Alasan memilih lokasi ini adalah karena terdapat simbol-simbol patung dan monumen yang dapat dijadikan kajian pembelajaran sejarah lokal. Kabupaten Ponorogo merupakan daerah yang memiliki potensi yang tinggi jika dilihat dari sejarah dan berbagai aspeknya, seperti patung dari tokoh babad Reog di depan Pendapa Kabupaten serta diperempatan Kota Ponorogo. Penelitian dilaksanakan mulai bulan Februari sampai Juli 2015.

Penelitian ini menggunakan pendekatan kualitatif. Pendekatan kualitatif adalah metode penelitian yang ditunjukkan untuk mendeskripsikan dan menganalisis fenomena, peristiwa, aktivitas sosial, sikap kepercayaan, presepsi, pemikiran orang, secara individual maupun kelompok (Sukmadinata, 2007: 60). Pendekatan penelitian berlandaskan pada filsafat postpositivisme, yang digunakan untuk meneliti kondisi obyek yang alamiah, dimana peneliti adalah sebagai instrumen kunci. Teknik pengumpulan data dilakukan secara triangulasi, analisis data bersifat induktif/kualitatif, dan hasil penelitian kualitatif lebih menekankan makna dari pada generalisasi (Sugiyono, 2009: 9).

Penelitian kualitatif digunakan dalam penelitian yang merujuk pada obyek dan fenomena yang terjadi secara alami. Hasil penelitian melalui pengamatan yang berisi deskripsi lengkap yang disertai hasil wawancara dan hasil analisis dokumen.Jenis penelitian, yaitu penelitian deskriptif. Bagian deskriptif dalam catatan data ini meliputi; potret subjek, rekonstruksi dialog, deskripsi keadaan fisik, struktur tentang tempat, dan barang-barang lain yang ada disekitarnya. Demikian juga, catatan tentang berbagai peristiwa khusus, termasuk siapa yang terlibat dengan cara bagaimana, gerakgeriknya, dan juga tingkah laku atau sikap penelitiannya (Sutopo, 2002: 74).

Senada dengan hal tersebut, penelitian deskriptif kualitatif bertujuan untuk menggambarkan, meringkas berbagai kondisi, berbagai situasi atau berbagai fenomena sosial yang berada pada masyarakat yang menjadi obyek penelitian dan berupaya menarik realita tersebut ke permukaan sebagai ciri, karakter, sifat, model, tanda, atau gambaran tentang suatu kondisi, situasi atau fenomena tertentu 
(Bungin, 2007: 68). Pendekatan ini cocok untuk meneliti tentang latar belakang sejarah patung dan monumen di Kabupaten Ponorogo, sehingga nilai-nilai kearifan lokal yang bisa diwariskan kepada masyarakat sebagai sumber belajar sejarah.

Penelitian ini dilaksanakan dengan menganalisis data yang diperoleh dari wawancara, dokumentasi, dan observasi langsung di lapangan. Sumber data penelitian ini merupakan sumber data primer dan sumber data sekunder yang dapat menjelaskan informasi yang diperlukan dalam penelitian. Sumber data pada penulisan ini diperoleh dari:

1. Sumber Data Primer

Data yang didapat berupa hasil wawancara dengan informan. Sumber lisan diperoleh dengan mendeskripsikan secara tertulis hasil pengamatan, wawancara,serta dokumentasi. Informan yaitu Dinas Kebudayaan Pariwisata Pemuda dan Olahraga (DISBUDPARPORA) Kabupaten Ponorogo sebagai pihak yang mewakili pemerintah Kabupaten Ponorogo.Kepala Desa Sumoroto, Kecamatan Kauman Ponorogo, dan beberapa sejarawan yang mengetahui pembangunan patung dan monumen waktu itu.

2. Sumber Data Sekunder

Sumber data sekunder dalam penelitian ini adalah sumber dokumen hasil observasi dan buku Babad Ponorogo Jilid IVII, data dari perpustakaan daerah Ponorogo, arsip, dokumen
DISBUDPARPORA dan BAPPEDA Ponorogo. Pengumpulan data dilakukan dengan wawancara, observasi, dan dokumentasi tertulis/arsip.

1. Wawancara

Wawancara dibagi menjadi beberapa bentuk dalam melakukan komunikasi lisan yaitu bentuk terstruktur, semi terstruktur, dan tidak terstruktur (Sugiyono, 2009: 233). Penelitian ini menggunakan jenis wawancara tidak terstruktur. Artinya, pedoman wawancara yang digunakan berupa garis besar permasalahan yang digunakan. Metode ini diharapkan menjadi kunci menjawab sejarah patung dan monumen di Ponorogo, sebagai sumber belajar sejarah lokal.

2. Observasi Langsung

Observasi dalam penelitian ini adalah peneliti mengamati simbol patung dan monumen di kawasan Ponorogo. Peneliti mendatangi lokasi, tetapi sama sekali tidak berperan sebagai apapun selain sebagai pengamat pasif.

3. Dokumentasi Tertulis/Arsip

Dokumen merupakan sumber data yang sering memiliki posisi penting penelitian kualitatif. Terutama bila sasaran kajian mengarah pada latar belakang atau berbagai peristiwa di masa lampau, dan berkaitan dengan kondisi atau peristiwa masa kini. Dokumen bisa memiliki beragam bentuk, dari yang tertulis sederhana sampai yang lengkap, dan bahkan bisa berupa 
benda lainnya sebagai peninggalan masa lampau (Sutopo, 2002: 69).

Teknik analisis isi dokumen digunakan untuk memperoleh data atau informasi yang bersumber dari dokumen atau arsip berupa buku tentang sejarah patung dan monumen di Ponorogo, sebagai sumber belajar sejarah lokal. Validitas data dalam penelitian ini, peneliti menggunakan teknik validitas data sebagai berikut:

1. Triangulasi metode adalah pengumpulan data yang sama dengan menggunakan metode pengumpulan data yang berbeda, serta diusahakan mengarah pada sumber data yang sama untuk menguji kemantapan informasi. Penggunaan metode pengumpulan data yang berbeda, dan bahkan lebih jelas untuk diusahakan mengarah pada sumber data yang sama untuk menguji kemantapan informasinya. Misalnya, untuk memantapkan validitas data mengenai suatu keterampilan seseorang dalam bidang tertentu. Peneliti bisa menggunakan metode pengumpulan data yang berupa kuesioner. Dilakukan wawancara mendalam pada informan yang sama dan hasilnya diuji dengam pengumpulan data sejenis dengan menggunakan teknik observasi pada saat orang tersebut melakukan kegiatannya atau perilakunya (Sutopo, 2002: 80).

2. Triangulasi sumber data adalah mengumpulkan data dari berbagai sumber data digunakan untuk menguji kebenaran tentang pelaksanaan pembelajaran bahasa Indonesia. Cara ini mengarahkan peneliti agar di dalam mengumpulkan data, ia wajib menggunakan beragam sumber data yang tersedia.

Artinya, data yang sama atau sejenis, akan lebih mantap kebenarannya bila digali dari beberapa sumber data yang berbeda. Triangulasi sumber data yang memanfaatkan jenis sumber data yang berbeda-beda untuk menggali data yang sejenis (Sutopo, 2002: 79).

3. Review informan merupakan usaha pengembangan validitas penelitian. Digunakan untuk mereview informan, apakah data hasil wawancara valid dan sesuai dengan kesepakatan atau belum.

Analisis data yang digunakan dari Miles dan Huberman (dalam Sugiyono, 2009: 246-253) yaitu analisis data interaktif dan berlangsung secara terus menerus melalui reduksi data, penyajian data, dan penarikan kesimpulan.

\section{Hasil dan Pembahasan}

\section{A. Latar Historis Patung dan Monumen di Ponorogo}

Ponorogo adalah kota budaya dan disebut juga kota Reog, hal ini bisa kita lihat dengan lahirnya kesenian Reog yang sudah melegenda serta diakui oleh UNESCO (United Nation Education Scientific and Cultural Organization) sebagai warisan budaya Indonesia, seharusnya kita bangga khususnya masyarakat Ponorogo sendiri, 
generasi muda berkewajiban senantiasa melestarikan kebudayaan tersebut. Oleh karena itu, pada eranya Bupati Dr. $\mathrm{H}$. Markom Singodimejo, MM yang banyak membangun patung-patung yang menunjukkan identitas Reog yang berada dikawasan kota Ponorogo, seperti patungpatung yang ada di permpatan dan kawasan alon-alon pendopo.

Hal ini bersamaan dengan rencana pemerintah untuk mensukseskan program kebersihan adipura, benar saja pada waktu itu kita mendapat piala adipura yang bisa kita lihat diperempatan pasar legi Songgolangit yang di monumentasikan. Patung-patung tersebut sengaja dibangun diberbagai sudut kota untuk trade mark keindahan kota, dan diharapkan Ponorogo menjadi kota Reog artinya kalau misal seseorang dari Madiun yang ingin berkunjung begitu masuk di kawasan Ponorogo dengan melihat patung-patung yang dibangun, akan merasakn nuansa Ponorogo sebagai kota Reog.

Pada waktu periode 1994 sampai dengan 2004 banyak pembangunan yang dilakukan pemerintah Ponorogo, salah satunya dengan pembangunan patungpatung yang tidak menggunakan anggaran daerah atau APBD. Hal ini tidak lepas dari kepiawean Bupati terdahulu yaitu Dr. H. Markum Singodimejo, MM yang dapat menarik investor dan peru-sahaan luar daerah untuk menyumbang bangunanbangunan yang sampai sekarang bisa kita lihat keberadaannya. Terkecuali, monumen Bantarangin dan patung Jathilan yang diresmikan Bupati H. Amin, SH dibangunn munggunakan anggaran APBD. Kota Ponorogo bila dilihat dari kebudayaan khususnya kesenian Reog, mestinya ketokohan patung yang dijadikan simbolsimbol di Ponorogo dapat dijadikan sumber pembelajaran sejarah lokal yang wajib dipelajari, karena generasi penerus harus diajarakan, sehingga mereka mengerti akan kearifan lokal budaya yang terdapat dalam cerita Reog Ponorogo.

Selama ini memang sudah ada instruksi dari dinas pendidikan agar tarian Reog dijadikan muatan lokal tetapi bisa kita lihat tidak semua sekolah di Ponorogo melakukan hal itu, yang terjadi dilapangan pembelajaran dilakukan hanya pada waktu mendekati event festival Reog gerebeng suro saja, dan tidak rutin dilakukan pada harihari biasa. Perawatan dan pelestarian simbol-simbol patung dan monumen di Ponorogo sudah semestinya ada perhatian yang lebih dari pemerintah terkait. karena simbol-simbol tersebut sudah menjadi ciri khas bahwa Ponorogo adalah kota Reog serta menjadi tata keindahan kota yang berbeda dengan kota-kota lain di Indonesia.

Oleh karena itu, dengan adanya patung dan monumen di Kabupaten Ponorogo yang dapat dikelola, serta dirawat secara maksimal bisa mendatangkan potensi-potensi yang lain bukan hanya terkenal dengan kota Reognya saja, tetapi 
bisa meningkatkan dunia kepariwisataan di Ponorogo sebagai kota patung yang unik menceritakan tentang simbol-simbol kebudayaan Reog Ponorogo yang arif.

\section{B. Makna Simbolis Patung di Kabupaten Ponorogo}

\section{Patung Dewi Songgolangit}

Patung Dewi Songgolagit menceritakan seorang gadis cantik yang berasal dari kerajaan Kediri, putri Sang Prabu Kertojoyo Kediri yang bernama asli Dewi Sanggrama Wijaya. Dalam cerita Reog yang sudah melegenda. Raja Bantarangin atau Prabu Klono Sewandhana berniat ingin meminang Dewi Songgolagit karena Klono Sewandhana sudah bersumpah tidak akan menikah dengan gadis idaman yang ditemukan di dalam mimpinya dan gadis yang diimpikan selama ini adalah Dewi Songgolagit. Patung ini sengaja ditempatkan di depan pendopo Kabupaten Ponorogo menghadap ke utara seolah tangan menyambut kedatangan masyarakat.

\section{Monumen Prabu Klono Sewandhana}

Monumen Klono Sewandhana yang dibagun di Dusun Bantarangin Desa Sumoroto Kecamatan Kauman Ponorogo. Mensimbolkan seorang Raja Bantarangin, yang bernama Prabu Klono Sewandhana yang mempunyai patih bernama Bujang Anom yang berkeinginan meminang Dewi Songgolangit putri dari Raja Kediri. Beliau adalah seorang raja muda yang gagah perkasa dan memiliki pusaka andalan berwujud sebuah cemeti, dikenel dengan nama pecut samandhiman oleh karena itu patung Klono Sewandhana berpose seolah memegang senjata pecut.

Patung Klono Sewandhana sengaja dibagun di Desa Sumoroto karena disana tempat petilasan kerajaan Bantarangin, yang dulu sering ditemukan beberapa peninggalan, berupa batu bata dan batu yang besar, Sekarang di tempat ini juga dibangun GOR (gedung olahraga) dan panggung utama yang digunakan untuk pementasan Reog, disana rutin dipentaskan pertunjukan Reog 2 bulan sekali atau sering dinamakan papakan tanggal jawa.

\section{Patung Bujang Anom}

Patung Bujang Anom atau pujonggo anom menceritakan seorang patih dari Kerajaan Bantarangin, satu perguruan dengan Klono Sewandhana dan mempunyai senjata topeng wasiat dari gurunya Ki Hajar Lawu. Ditinjau dari namanya patih yang satu ini adalah orang pintar dalam berbagai ilmu yang masih muda usianya (Soemarto, 2014: 05)

Patung Bujang Anom dibangun di dua lokasi perempatan yang menghadap ke barat dan timur, hal ini seolah menyimbulkan Bujang Anom pergi dan kembali dari Kerajaan Kediri, karena ditugaskan Raja Bantarangin untuk melamar Dewi Songgolangit.

Sesampainya di istana Raja Kediri menyuruh melepas topeng Bujang Anom tetapi dia menolak kemudian raja marah dan menyumpah bahwa topengnya tidak 
dapat dilepas, sepulang dari Kediri Bujang Anom tidak bisa melepas topengnya karena sumpah Raja Kediri.

\section{Patung Warok Ponorogo}

Patung Warok menceritakan seseorang yang mempuyai kelebihan baik ilmu kanuragan dan ilmu kebatinan, serta tirakatnya kuat. Mereka para warok ini, memerintah beberapa desa dengan penuh kesewenangan (Purwowijoyo, 1990: 30). Patung Warok sengaja dibangun di dua lokasi perempatan kota hal ini untuk menunjukan kesan bahwa, dulu kota Ponorogo mempunyai tokoh Warok. Dahulu untuk mendapatkan julukan Warok tidak mudah bagi seseorang. Ada beberapa persyaratan yang harus dipenuhi. Seorang warok harus menjalankan berbagai laku/lelakon atau syarat-syarat yang tidak mudah untuk dijalani.

Syaratnya antara lain adalah harus mempunyai hati yang bersih karena jiwanya akan diisi kesaktian tertentu, serta tidak diperkenankan menikah karena kalau seorang Warok menyentuh perempuan konon kesaktiannya akan luntur. Oleh sebab itu seorang Warok memelihara gemblak (kongkonan atau suruhan yang menemani kemanapun Warok pergi seorang laki-laki berumur belasan tahun berparas tampan). Konon seorang Warok mempunyai senjata pamungkas yang bernama kolor sakti.

\section{Patung Jathilan}

Patung jathilan dibangun dan diabadikan dalam berbagai kelompok patung Reog, salah satunya yang berada di dibangun disebelah selatan Stadion Batoro Katong. Guna pembangunan untuk menghiasi artistik pintu masuk Stadion dari arah selatan. Langsung terlihat jelas bila dilihat dari selatan Jalan Baru atau Jalan Suromenggolo.

Simbol ketokohan Jatilan melambangkan prajurit perang yang gagah mengendarai kuda, dahulu seorang Jathil diperankan oleh seorang laki-laki yang usianya diantara 12 sampai 15 tahun, dan dipelihara oleh seorang Warok, Jathil lakilaki disebut gemblak ramai sekitar tahun 1960-an. Menjelang tahun 1978 memang sudah mulai ada kelompok Reog Ponorogo yang menampilkan penari jathil yang diperankan penari perempuan. Akibatnya, Departemen P dan K Kabupaten Ponorogo melalui Kasi III mengeluarkan surat larangan tentang penari jathil yang diperankan oleh perempuan, surat larangan tersebut tertanggal 1 Juni 1978 nomor 644/II.19/J.78 (Soemarto, 2014: 20). Setelah itu beredar sebaliknya, sejak saat itu penari jathil diperankan oleh perempuan.

Alasannya memang mendasar, anak laki-laki sudah tidak mau lagi menarikan tokoh jathilan, sedangkan dari sisi lain merupakan hak asasi dan partisipasi bagi anak perempuan dalam berolah seni (tari). Tahun 1980-an, pemerintah Ponorogo diminta mengirimkan 100 unit kesenian Reog Ponorogo oleh pemerintah DKI Jakarta untuk memeriahkan pembukaan Pekan 
Raya Jakarta. Untuk itu pasti diperlukan penari jathil sebanyak 3-4 anak dikalikan 100 unit Reog Ponorogo. Hal ini untuk mendapatkan penari jathilan laki-laki (gemblakan) sebanyak itu ternyata menemui kendala karena jumlah gemlakan sudah tidak mencukupi.

Untuk memenuhi hal itu seniman Reog menunjuk siswi SMK (SMEA) untuk dilatih menari jathil dan hasilnya pun sangat memuaskan, sejak saat itu penari jathil yang semula kebanyakan diperankan oleh lakilaki (gemblakan) sekarang bergeser menjadi perempuan yang memerankan.

\section{Patung Macan}

Makna simbolis patung macan adalah seorang tokoh Singo Barong yang berasal dari hutan Lodoyo akhirnya mendapat julukan Singo Lodro yang dikatakan dalam cerita Reog (versi Bantarangin) menghadang perjalanan Klono Sewndhana karena tidak terima putri Songgolangit dilamar tetapi Singo Lodro dapat dikalahkan Klono Sewandhana dengan senjatanya yaitu pecut samandiman. Patung macan banyak dibangun di Ponorogo, dikarenakan macan adalah simbol-simbol reog (disebut juga singo barong).

Oleh karena itu, sosok macan dalam kesenian Reog tidak asing lagi. Kata Reog dahulu menurut orang Jawa berawal kata soyok yang mempunyai arti gotong royong, jadi Reog mempunyai bisa dartikan gotong royong. Kesenian Reog Ponorogo yang merupakan salah satu kesenian daerah di Indonesia ini memang belum banyak dibukukan. Cerita Reog Ponorogo memang penyampaiannya dari cerita tutur yang dilakukan secara turun-temurun leh para pedahulu, wajar apabila kesenian ini memiliki banyak versi dan penafsiran oleh masyarakat.

\section{Potensi Monumen di Ponorogo Sebagai Pembelajaran Sejarah Lokal}

Kota Ponorogo terdapat banyak patung dan monument. Hal ini bisa dilihat disetiap perempatan dan lokasi sentral Ponorogo. Aspek keindahan kota dengan keberadaan patung dan monumen dapat mendatangkan potensi-potensi dalam menambah kajian pembelajaran sejarah yang arif. Kajian sejarah lokal akan mampu menambah pengetahuan baru, dan dapat menarik para wisatawan untuk berkunjung ke Ponorogo.

Nilai-nilai filosofi yang terdapat dalam simbol-simbol patung di Ponorogo patut dikaji mendalam serta dapat dijadikan sejarah lokal, banyak generasi muda sekarang ini kurang memahami pentingnya peninggalan bersejarah, terutama untuk siswa SMP sangat cocok diajarkan sejarah lokal, karena masih tahap awal dalam mempelajari mata pelajaran sejarah.

Sebenarnya jika sejarah mampu dipelajari sejak dini dan disampaikan dengan benar maka akan banyak siswa yang tertarik terhadap mata pelajaran IPS Sejarah, namun kenyataan yang selama ini 
terjadi adalah banyak sekali siswa, khususnya siswa SMP kurang menyukai mata pelajaran satu ini. Salah satu faktornya adalah dari pengajar atau guru, guru merupakan kunci utama siswa dalam menerima segala hal yang berkaitan dengan hal kegiatan sekolah terutama dalam proses belajar mengajar.

Jika guru mampu mentransfer ilmu dengan baik dan menerapkan pengajaran yang menyenangkan, serta mengunakan media pembelajaran yang lebih menarik. Maka guru juga harus menciptakan media pembelajaran yang lebih kreatif supaya dapat meningkatkan semangat siswa untuk terus belajar dan menambah wawasan terhadap sejarah lokal. Sehingga harapan kedepan dapat dijadikan materi dalam muatan lokal sekolah di Ponorogo agar generasi penerus lebih mengerti akan sejarah kotanya.

\section{Penutup}

\section{Kesimpulan}

Bila dilihat dari latar belakang historis yang ada, Ponorogo mempunyai kesenian yang sudah melegenda sejak dahulu yaitu kesenian Reog. Dalam perkembanganya bermunculan juga patungpatung serta monumen yang patut dikaji mendalam. Simbolis dan sejarah yang tersirat dalam pembuatan bangunan tesebut, nantinya dapat dipelajari dan menjadi sebuah pembelajaran sejarah lokal Ponorogo. Peran Bupati terdahulu yaitu Dr. H. Markom Singodimejo, MM sangatlah besar dalam pembangunan patung-patung dikawasan Ponorogo, dan berkat kepiaweannya, Beliau dapat mendatangkan investor-investor dari luar daerah untuk menyumbang bangunan patung tersebut.

Banyak peninggalan patung yang bernuansa cerita Reog Ponorogo yang berada di perempatan jalan kota, pendopo Kabupaten, maupun dikawasan alon-alon Ponorogo. Hal ini bisa menambah trade mark keindahan kota yang berbeda dari daerah-daerah lain yang ada di Indonesia. Apabila dilihat dari aspek artistik bisa dikatakan simbol-simbol tersebut unik. jika dikelola dengan baik akan menambah kajian pembelajaran sejarah yang arif. Kajian sejarah lokal akan mampu menambah pengetahuan baru, serta dapat menarik para wisatawan ke Ponorogo.

Ponorogo tidak hanya dikenal sebagai kota Reog tetapi seiring perkembanganya dijuluki kota patung yang khas.Nilai-nilai filosofi yang terdapat dalam simbol patung di Ponorogo perlu dikaji mendalam, serta dapat dijadikan potensi pembelajaran sejarah lokal, sehingga dapat dijadikan materi dalam muatan lokal sekolah di Ponorogo agar generasi penerus akan lebih mengerti sejarah kotanya.

\section{Daftar Pustaka}

Achmad Fedyani Saifuddin. 2006. Antropologi Kontemporer: Suatu Pengantar Kritis Mengenai Paradigma. Jakarta: Kencana. 
Andi Prastowo. 2014. Memahami MetodeMetode Penelitian. Jogjakarta: Ar-Ruzz Media.

Burhan Bungin. 2007. Penelitian Kualitatif. Jakarta: Prenada Media Grafika.

Badan Pusat Statistik Kabupaten Ponorogo. 2014. Ponorogo dalam Angka 2014. Ponorogo: BPS Kabupaten Ponorogo.

Budiono Herusatoto. 2008. Simbolisme Jawa. Yogtakarta: Ombak

B.P. Sitepu. 2014. Pengembangan Sumber Belajar.Jakarta: PT Raja Grafindo Persada.

Departemen Pendidikan Nasional. 2008. Kamus Besar Bahasa Indonesia Pusat Bahasa. Jakarta: PT Gramedia Pustaka Utama.

Dinas Permukiman dan Prasarana Wilayah. 2008. Penyusunan dan Analisa Data/Informasi Pengolahan Ruang Terbuka Hijau Perkotaan Adipura Ponorogo. Ponorogo: BPU Kabupaten Ponorogo.

Eko Praptanto. 2010. Sejarah Indonesia Zaman Orde Lama. Jakarta: Bina Sumber Daya MIPA

Eriyandi Budiman. 2008. Seni Rupa Nusantara. Bandung: CV. Gaza Publishing.

Haris Herdiansyah. 2010. Metodologi Penelitian Kualitatif untuk IImu-IImu Sosial

H. B. Sutopo. 2002. Metodologi Penelitian Kualitatif. Surakarta: Universitas Sebelas Maret.

Iqbal Hasan. 2004. Analisis Data Penelitian dengan Statistik. Jakarta:Bumi Aksara

Lexy J. Moleong. 2011. Metodologi Penelitian Kualitatif. Bandung: Remaja Rodakarya.

Martinis Yamin, 2013. Paradigma Baru Pembelajaran. Jakarta: Anggota IKAPI.

Nana Syaodih Sukmadinata, 2007. Metode Penelitian Pendidikan. Bandung: PT Remaja Rosdakarya.

Nazir, 2011. Metode Penelitian. Bogor: Ghalia Indonesia.
Purnawan Basundoro. 2012. Pengantar Sejarah Kota. Yogyakarta: Ombak

Purwowijoyo. 1990. Babad Ponorogo Jilid IVII, Ponorogo: Dinas Pariwisata dan Seni Budaya Kabupaten Ponorogo.

Wina Sanjaya. 2006. Strategi Pembelajaran Berorientasi Standar Proses Pendidikan. Jakarta: Fajar Interpratama Offset.

Ririn Darini. 2013. Sejarah Kebudayaan Indonesia. Yogyakarta: Ombak.

Saefur Rochmat. 2009. Ilmu Sejarah Dalam Perspektif Ilmu Sosial. Yogyakarta: Graha Ilmu.

Slameto. 1991. Proses Belajar Mengajar Dalam Sistem Kredit Semester (SKS). Jakarta: Bumi Aksara.

Sugeng Priyadi. 2012. Sejarah Lokal: Konsep, Metode, dan Tantangannya. Yogyakarta: Ombak Dua.

Soemarto, 2011. Melihat Ponorogo Lebih Dekat. Ponorogo: Dinas Pariwisata dan Seni Budaya Kabupaten Ponorogo.

Soemarto, 2014. Menelusuri Perjalana Reog Ponorogo. Ponorogo: CV. Kota Reog Media.

Sugiyono, 2009. Metode Penelitian Kuantitatif Kualitatif dan R\&D. Bandung: Alfabeta.

Taufik Abdullah, 1990. Sejarah Lokal di Indonesia Kumpulan Tulisan. Yogyakarta: Universitas Gajah Mada. 